\title{
Web Planning Tower Base Transceiver Station Collective Mobile Telecommunications in Merauke City Based On Geographic Information Systems Using Mapinfo For The Next 10 Years
}

\author{
Roberto Corputy ${ }^{1 *}$, Marsujitullah Marsujitullah ${ }^{2}$, Zahir Zainuddin ${ }^{3}$, and Sirin Rezkyca Maulani ${ }^{1}$ \\ ${ }^{1}$ Department of Electrical Engineering, Faculty of Engineering, Universitas Musamus, Merauke 99600, Indonesia \\ ${ }^{2}$ Department of Informatics, Faculty of Engineering, Universitas Musamus, Merauke 99600, Indonesia \\ ${ }^{3}$ Department of Electrical Engineering, Faculty of Engineering, Universitas Hasanuddin, Gowa 92171, Indonesia
}

\begin{abstract}
The purpose of this study is to develop a master plan for mapping joint cellular telecommunication BTS towers in accordance with the Regulation of the Minister of Communication and Information Number : 02/Per/M.Kominfo/03/2008 regarding the use of towers together. The method used to collect and process data and analyze the distribution zone using MapInfo software. The data collection was an existing BTS towers and population which calculating and find the need of towers in the future by calculating the number of residents, users, traffic, then processed to calculate the number of BTS and shared towers and through coverage the possible distribution zones of the towers described through MapInfo are determined. The results obtained are a master plan containing predictions of the need for BTS towers in 2029 as many as 43 BTS with each tower occupied by a maximum of 3 providers so as to minimize the occurrence of tower forests and an overview of the pattern regarding the distribution of shared towers using the MapInfo software.
\end{abstract}

Keywords: Base Transceiver Station, MapInfo, distribution zones

\section{Introduction}

Telecommunications technology continues to develop due to its role in being able to reach long distances globally. This telecommunication really helps people to communicate with each other regardless of how far apart they are. The greater the needs of this community will increasingly encourage the development of telecommunications technology that occurs, which of course cannot be separated from the industry. The telecommunications industry, which is seen as the backbone of the modern digital world, is required to continuously make progress in the evolution of the telecommunications network system, because the network is the main key to technology in order to remain in touch with each other so that it is necessary to improve facilities that support the quality of the telecommunications network system, such as towers. telecommunication. Telecommunications towers including BTS (Base Transceiver Station) are the main infrastructure for users to access the network [1].

The population (human) will continue to increase. This population rate has resulted in more and more cellular phone users or subscribers, thus increasing the density of telecommunication traffic. As a result, communication needs are also increasing which has an impact on increasing the need for telecommunication towers in Indonesia to support the quality of cellular networks, including in Merauke City. Based on the results of a survey conducted at the Communications and Information Technology Office, the existing Telecommunication BTS towers in Merauke City until 2019 reached 60 towers with 3 providers including Telkomsel, XL Axiata and Indosat Ooredoo. Each provider has a different number of BTS that have been spread across the city of Merauke. The 60 BTS towers belonging to various companies to the government serve 100,021 people spread over $123.11 \mathrm{~km} 2$ [2]. The distribution of this tower is carried out by reviewing user needs, so it must be remembered that the population rate will continue to increase so that new cellular telecommunications BTS towers will continue to be needed.

The construction of telecommunication towers needs to pay attention to several things including the availability of land, buildings and air space. In the Regulation of the Minister of Communication and Information Number: 02/Per/M.Kominfo/03/2008 concerning Guidelines for the Development and Use of Shared Telecommunication Towers, it has been explained that the obligation to use towers together with due regard to the continuous growth of the telecommunications industry so that the cellular telecommunication BTS towers that are built must

\footnotetext{
*Corresponding author:roberto@unmus.ac.id
} 
comply with the stipulated requirements in order to avoid the occurrence of telecommunication tower forests, as well as to minimize the potential for security conflicts in the community. In addition, it is also necessary to pay attention to public health and environmental aesthetics, due to long-term telecommunications towers [3]. Based on the problems above, it is also seen that the condition of the cellular telecommunications BTS towers in Merauke City which are still being built are separated between providers. Meanwhile, on the other hand, it can also minimize the negative impacts that will disturb the community.

\section{Supporting Theory}

\subsection{Global System of Mobile Communication Technology}

GSM technology is a technology that is widely applied in mobile communications, one of which is mobile phones. This technology is digital. GSM technology works by utilizing microwaves and the process of sending this technology is divided by time [4]. GSM architecture in general can be seen in Figure 1.

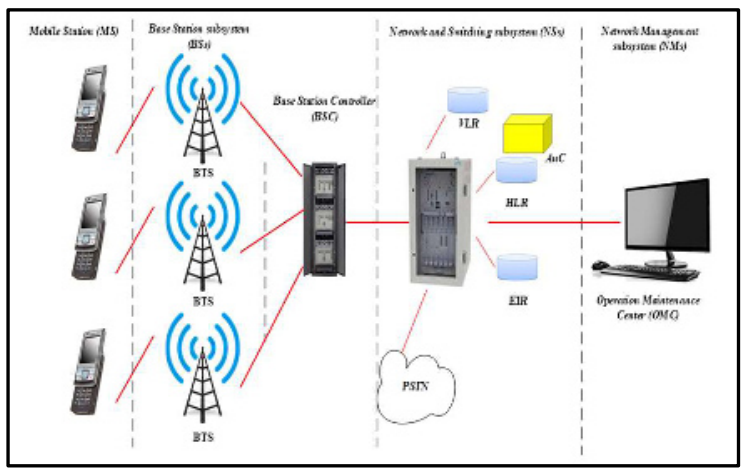

Fig. 1. GSM architecture.

From Figure 1, it can be seen that the GSM architecture consists of:

a) The Mobile Station subsystem (MSs) consists of Mobile Stations, which are components of devices used to communicate by subscribers. The MS in question is a physical device that is used with a Subscriber Identity Module (SIM) or smart card. Because without a SIM, MS can only be used on emergency traffic lines.

b) Base Station subsystem (BSs) which has the function of being in charge of each connected BTS radio so that it controls the work of the BTS and handles call handovers between cells controlled by the BSC. In addition to the BSC, there is also a Base Transceiver Station (BTS) which functions to handle the interface or direct connection with the MS and also functions as a signal sender and receiver.

c) Network and Switching subsystem that functions as a call process controller and is responsible for the functions of components related to customers. This stage consists of MSC (Mobile Switching
Controller), HLR (Home Location Register), and VLR (Visitor Location Register). MSC is the core of the GSM network that functions as network interconnection. HLR serves as a permanent database for all data from customers. For VLR, it functions as a temporary customer information database. In addition, there is also an $\mathrm{AuC}$ (Authentication Center $(\mathrm{AuC})$ which functions to confirm the user's identity and keeps call secrets and EIR (Equipment Identity Register) which functions as an MS database.

d) Network Management subsystem, namely the Operation and Support System is a subsystem of the GSM network that functions as a control center including fault management, configuration management, and inventory management [5].

\subsection{Telecommunications Tower}

Shared telecommunication tower is a term for the provisions of regulations for the construction of towers and the joint use of telecommunication towers based on government regulations. With this, the government intends to minimize as well as make the best use of the land space for the construction of the tower. Even so, this must also take into account the stability of the growth of the telecommunications industry.

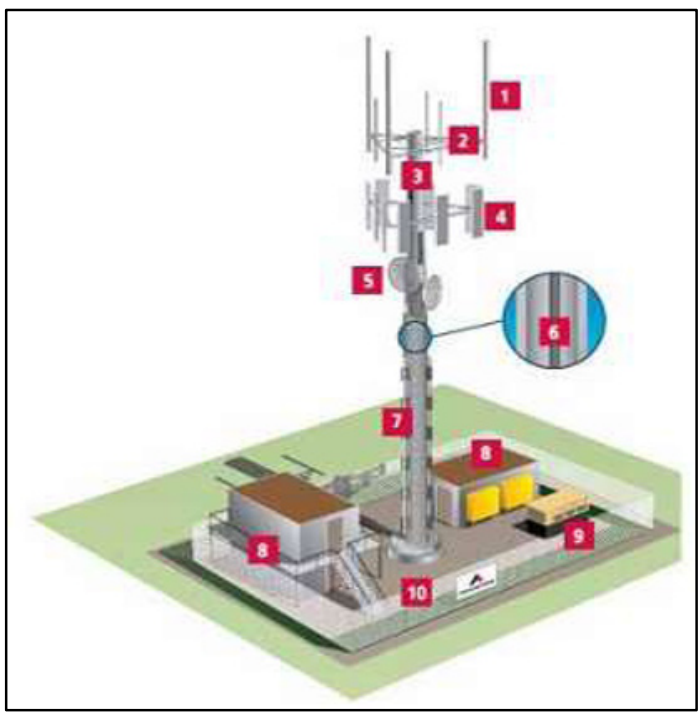

Fig. 2. Telecommunication Tower Components.

Based on the place of establishment, towers include two types, namely towers built on the ground (green field) and towers built on top of buildings (roof top) [3]. Meanwhile, based on its structure, the telecommunication BTS tower is divided into 3, namely [4].

\subsection{Calculation Data in Supporting Needs}

Geographical Information System or often referred to as Geospatial Information System is an information system used to compile, store, revise and analyze data and attributes that refer to the location or position of objects 
on earth [7]. This means that data or information that refers to the location or position of objects on earth is termed spatial data or information, while attributes describe the characteristics of the spatial data. More specifically, the components of spatial data include geographic position / location, attribute data, spatial relationships and time.

The calculation support is divided into several categories, which can be explained as follows:

\section{a) Traffic Capacity}

The amount of traffic is measured in units of time where the value of the traffic of the channel is obtained from the length of time it has been occupied by the channel. One of the purposes of the traffic calculation is to determine the network performance and the quality of service of the telecommunications network, The traffic capacity can be calculated by the call average [8]:

$$
\alpha=\mathrm{c} / \mathrm{T}
$$

And the traffic volume can be determined by:

$$
\mathrm{V}=\mathrm{Ch}
$$

So that the traffic intensity is obtained by:

$$
\mathrm{A}=\mathrm{v} / \mathrm{T}=\alpha \mathrm{h}
$$

Where:

$\mathrm{A}=$ traffic intensity (Erlang)

$\alpha=$ average of calls in time unit (Calls/Hour)

$\mathrm{C}=$ number of calls (Calls)

$\mathrm{T}=$ unit of time (hours)

$\mathrm{V}=$ traffic volume (Calls/Hour)

$\mathrm{h}=$ mean holding time (Hours)

The total traffic generated by all customers is:

$$
T=P \times A
$$

Where:

$\mathrm{T}=$ Total traffic generated by customers (Erlang).

$\mathrm{P}=$ Number of mobile subscribers

$\mathrm{A}=$ Erlang per customer

\section{b) Growth Rate Statistics}

Where:

$$
\begin{aligned}
& r=\left(\frac{P t}{P_{0}}\right)^{\frac{1}{t}}-1 \\
& P_{t}=P_{0}(1+r)^{t}
\end{aligned}
$$

$P_{t}=$ Total population in year $\mathrm{t}$

$P_{0}=$ Initial population

$r=$ Population growth rate

\section{c) BTS Tower Needs}

Mobile Telecommunications

$$
\mathrm{B}=\mathrm{N} / \mathrm{A}
$$

Where,

$\mathrm{B}=$ Number of BTS needs

$\mathrm{T}=$ Total traffic of all cellular subscribers (Erlang)

$\mathrm{A}=$ Capacity of one BTS (Erlang)

The number of tower requirements can be obtained by the formula as following:

\section{$\mathrm{Mt}=\mathrm{Bt} / 3$}

\section{d) Number of Mobile Users}

$$
\mathrm{P}=\mathrm{x} \% \mathrm{xPt}
$$

Where:

$\mathrm{P}=$ Cellular teledensity

$\mathrm{x}=$ Percentage of mobile phone users

\section{e) MapsInfo}

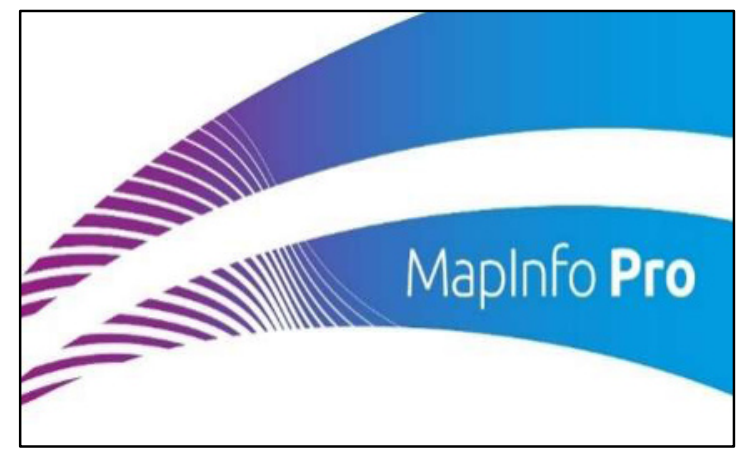

Fig. 3. MapInfo Application Display

MapInfo is a Geographic Information System (GIS)based software that has a function for managing maps in the form of spatial data or in the form of excel data, based data and the like with a user friendly display that makes it easy for users. Software has the ability to combine and display a single map with data from various sources, formats, and projections [6].

\section{Methods}

There are several stages of research procedures carried out in this study, namely research data collection methods, Data Processing Methods and Modeling Methods for Telecommunication BTS Tower Structure Design.

The research data collection method consists of:

1. Study of literature

2. Observation

3. Secondary data collection.

Then the following stages apply data processing methods which include: 
1. Estimated Total Population Growth

2. Estimated Number of Cellular Service User Growth

3. Traffic Capacity Calculation

4. Propagation Calculation

5. Calculation of the Number of BTS and Telecommunication Tower

6. BTS Tower Mapping Using MapInfo, as well as

7. Conclusion.

In addition to data collection methods and data processing methods, the application of the Telecommunication BTS Tower Structure Design Modeling Method is also carried out by carrying out two important aspects, namely:

1. Determining the Location of BTS and

2. Determination of Control Equipment Location Points for Each Provider.

\section{Location of Research, Data Analysis, Implementation Results and Validation}

\subsection{Calculation Data in Supporting Needs}

The research location and data collection were carried out in the Merauke city area. The Merauke city area in question is an urban area of the Merauke district which consists of 11 villages, namely Jungle Jaya Village, Kelapa Lima Village, Maro Village, Mandala Village, Samkai Village, Karang Indah Village, Bamboo Pemali Village, Seringgu Jaya Village, Muli Village, Subdistrict Kamundu, and Kamahedoga Village.

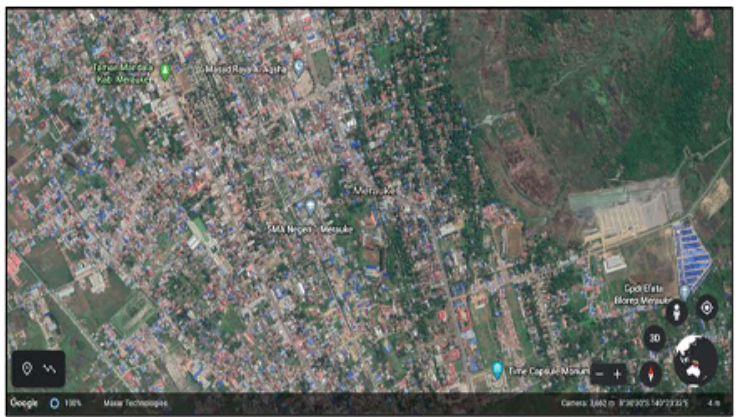

Fig. 4. Research Sites

\subsection{System Analysis}

System analysis is divided into two categories, namely the current system and the proposed system. In a running system, this process can describe the work system that is currently being implemented by the company to build towers. The following is a running system analysis of the tower construction process.

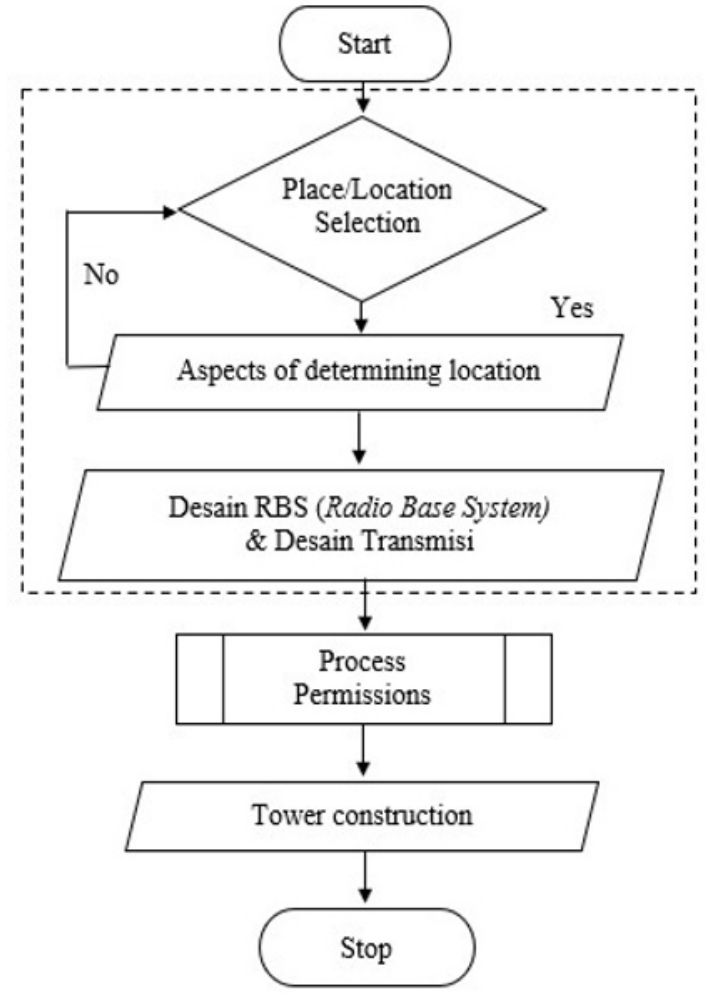

Fig. 5. Running System Analysis Chart

\subsection{Implementation Results}

\subsubsection{Prediction of Population Growth}

This population prediction is to estimate the population in 2029. The following is an example of calculating growth predictions in Rimba Jaya Village:

With

$$
\begin{gathered}
r=\left(\frac{P_{t}}{P_{0}}\right)^{\frac{1}{t}}-1 \\
r=\left(\frac{19.741}{16.951}\right)^{\frac{1}{10}}-1 \\
r=0,0153=1,53 \%
\end{gathered}
$$

Then

$$
\begin{gathered}
P_{t}=P_{0}(1+r)^{t} \\
P_{2029}=19.741(1+0,0153)^{10} \\
P_{2029}=22.990 \text { Population. }
\end{gathered}
$$


Table 1. Prediction Results of Population in Merauke City in 2029

\begin{tabular}{|c|c|c|c|c|c|c|}
\hline \multirow[t]{2}{*}{ No } & \multirow[t]{2}{*}{ Village } & \multicolumn{2}{|c|}{$\begin{array}{c}\begin{array}{c}\text { Number of Population } \\
\text { (people) }\end{array} \\
\end{array}$} & \multirow{2}{*}{$\begin{array}{l}\text { Difference } \\
2019-2029\end{array}$} & \multirow{2}{*}{$\begin{array}{l}\text { Growth Rate } \\
r=\left(\frac{P_{t}}{P_{0}}\right)^{\frac{1}{t}}-1\end{array}$} & $\begin{array}{c}2029 \text { Population } \\
\text { Growth Prediction }\end{array}$ \\
\hline & & 2009 & 2019 & & & $P_{t} \quad=P_{0}(1+r)^{t}$ \\
\hline 1 & Rimba Jaya* & 16.951 & 19741 & 10 & 1.53 & 22.990 \\
\hline 2 & Kelapa Lima* & 13.809 & 16.124 & 10 & 1.56 & 18.827 \\
\hline 3 & Maro* & 13.011 & 14.463 & 10 & 1.06 & 16.077 \\
\hline 4 & Mandala & 14.380 & 16.552 & 10 & 1.42 & 19.052 \\
\hline 5 & Samkai & 7.137 & 8.393 & 10 & 1.63 & 9.870 \\
\hline 6 & Karang Indah & 7.534 & 8.787 & 10 & 1.55 & 10.248 \\
\hline 7 & Bambu Pemali & 7.017 & 7.955 & 10 & 1.26 & 9.018 \\
\hline 8 & Seringgu Jaya & 6.907 & 8.006 & 10 & 1.49 & 9.280 \\
\hline 9 & Muli** & - & - & - & - & - \\
\hline 10 & Kamundu** & - & - & - & - & - \\
\hline 11 & Kamahedoga** & - & - & - & - & - \\
\hline & Total $/ \bar{x}$ & 88.755 & 102.040 & 10 & 1.43 & 115.363 \\
\hline
\end{tabular}

*) The total population in the kelurahan is still the combined population data before the division.

**) Villages resulting from the division of the Rimba Jaya village. So that the population data and the results of calculations in these kelurahan are still counted in the kelurahan before the division.

\section{a) Predict the Number of Cell Phone Users}

With cellular teledensity in Merauke city of $66.19 \%$, the number of cellular phone users can be calculated using the formula with the example in Rimba Jaya Village as follows:

$$
\begin{gathered}
P=X \% x P_{t} \\
P=66,19 \% x P_{2029} \\
P=66,19 \% x 22.990 \\
P=15.217 \text { customer }
\end{gathered}
$$

\begin{tabular}{|c|c|c|c|}
\hline \multirow[t]{2}{*}{ No } & \multirow[t]{2}{*}{ Village } & $\begin{array}{c}\text { Total } \\
\text { population } \\
\text { (soul) }\end{array}$ & $\begin{array}{c}\text { Number of } \\
\text { Mobile Usesrs } \\
\text { (customer) }\end{array}$ \\
\hline & & 2029 & $\boldsymbol{P}=\boldsymbol{X} \% \boldsymbol{x}-\boldsymbol{P}_{\boldsymbol{t}}$ \\
\hline 1 & Rimba Jaya* & 22.990 & 15.217 \\
\hline 2 & Kelapa Lima* & 18.827 & 12.462 \\
\hline 3 & Maro* & 16.077 & 10.641 \\
\hline 4 & Mandala & 19.052 & 12.611 \\
\hline 5 & Samkai & 9.870 & 6.533 \\
\hline 6 & Karang Indah & 10.248 & 6.783 \\
\hline 7 & Bambu Pemali & 9.018 & 5.969 \\
\hline 8 & Seringgu Jaya & 9.280 & 6.142 \\
\hline 9 & Muli** & - & - \\
\hline 10 & Kamundu** & - & - \\
\hline 11 & Kamahedoga** & - & - \\
\hline & Total & 115.362 & 76.358 \\
\hline
\end{tabular}

Table 2. Prediction Results of Population in Merauke City in 2029

*) The total population in the kelurahan is still the combined population data before the division.

**) Villages resulting from the division of the Rimba Jaya village. So that the population data and the results of calculations in these kelurahan are still counted in the kelurahan before the division.

\section{b) Existing Tower Condition}

From the calculation of the predicted population in 2029 and the number of cellular phone users in 2029 , the need for telecommunication towers can be obtained by calculating and mapping the traffic capacity of existing towers to obtain the number of BTS and new telecommunication towers so that the location of the new tower site can be positioned accordingly, with the existing tower zone 2019. The existing telecommunication BTS (Base Transceiver Station) tower is a tower that has existed before in Merauke City. With an area of $123.11 \mathrm{~km} 2$, there are 60 existing Telecommunication BTS towers spread across the city of Merauke until 2019. This data was obtained from the Communications and Information Office in the form of the number of BTS towers, the location of the BTS tower coordinates and the height of the BTS tower.

\section{Conclusion}

Based on the results of data processing obtained by predicting the population in 2029 , the prediction of the number of users, the prediction of the total traffic generated, the prediction of the number of BTS needed and the number of towers needed, the following conclusions can be drawn

1. In Merauke City there are 60 existing towers each with each tower being operated by 1 operator.

2. From the results of data analysis and data processing that has been carried out, it is found that the number of towers with the determination of the use of shared towers is a maximum of 1 tower operated by 3 operators with a tower capacity of 3 BTS as many as 14 towers with a total BTS of 43 BTS capable of serving 76,358 cellular users with a total traffic of 2,386 Erlang. 


\section{References}

1. Menteri Dalam Negeri, Menteri Pekerjaan Umum, Menteri Komunikasi dan Informatika, and dan Kepala Badan Koordinasi Penanaman Modal, Pedoman Pembangunan Dan Penggunaan Bersama Menara Telekomunikasi. (2009).

2. S. Budiyanto, "Teknologi GSM Dan Pertumbuhan Pelanggan Seluler Di Indonesia," FT, Univ. Indones., vol. 2000, pp. 4-30, (2010)

3. A. G. Palilu, "Studi Awal Perencanaan Jumlah Kebutuhan BTS dalam Penerapan Menara Bersama Telekomunikasi di Kota Palangka Raya," Bul. Pos dan Telekomun., vol. 12, no. 4, p. 269, (2015).

4. T. Sst, S. Pro, S. Pro, S. Standard, and S. A. Towers, "Analisa Struktur Tower Bts Berdasarkan Hasil Re - Verticality Menggunakan Staad Pro," pp. 1-33

5. A. A. Z. Dewi Purnamasari, Imam Santoso, "Analisis Kapasitas Kanal Trafik Bts Pada Jaringan CDMA 450 Untuk Layanan Suara," Univ. Diponegoro, no. August, pp. 1-10, (2015).

6. Marsujitullah and Deril Alfiance Kaligis, "Interpretasi pertumbuhan tanaman padi dengan citra berbasis drone berdasarkan nilai histogram' Mustek Anim Ha. vol. 8, no. 3,p-ISSN. 2089-6697, (2019).

7. F. X. Marsujitullah and R. Manggau, "Classification Of Paddy Growth Age Detection Through Aerial Photograph Drone Devices Using Support Vector Machine And Histogram Methods, Case Study Of Merauke Regency Students' Perceptions towards the Grammar Teaching at English Literature Department of," Artic. ID IJMET_10_03_187 Int. J. Mech. Eng. Technol., vol. 10, no. 3, pp. 1850-1859, (2019).

8. Marsujitullah, F.X Manggau, Daniel Parenden. Interpretation of Food Crop Growth Progress Visualization and Prediction of Drone Based Production Estimates Based on Histogram Values in Government Areas -Case Study of Merauke Regency, IOP Conf. Ser.: Mater. Sci. Eng. 1125 012102, (2021) 